\begin{tabular}{|c|c|}
\hline & $\begin{array}{l}\text { International Journal of Trend in Scientific } \\
\text { Research and Development (IJTSRD) }\end{array}$ \\
\hline 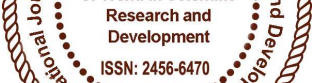 & International Open Access Journal \\
\hline 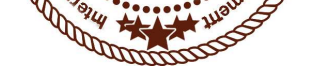 & ISSN No: 2456 - 6470 | www.ijtsrd.com | Volume - 2 | Issue - 2 \\
\hline
\end{tabular}

\title{
Quality of Water for Irrigating Urban Vegetable Farms: An assessment of Toxic and Essential Metals in Water from an Urban Lake
}

\section{Edna Dzifa Doe}

Cellular and Clinical Research Centre, Radiological and Medical Sciences Research Institute, Ghana

Atomic Energy Commission, Accra, Ghana

\section{Nash O. Bentil}

Nuclear Chemistry and Environmental Science Research Centre,National Nuclear Research Institute, Ghana Atomic Energy Commission, Accra, Ghana

\section{Adolf Kofi Awua}

Cellular and Clinical Research Centre, Radiological and Medical Sciences Research Institute, Ghana Atomic Energy Commission, Accra, Ghana

\section{ABSTRACT}

In order to advise farmers as to which source of water will be best to draw from for irrigation in order to avoid or minimize the potential of the risk of heavy metal contamination of their vegetables, this study determined the concentrations of selected heavy metals and some physicochemical indicators of the quality of water from along the bank of the Marina Park Lake, which we recollected according to the guidelines of the American Public Health Association. Metals were analysed for with an Atomic Absorption Spectrophotometer and the concentration of the detected metals were within the ranges of 0.628 to $1.816 \mathrm{mg} / \mathrm{L}$ for $\mathrm{Fe},<0.002$ to $0.051 \mathrm{mg} / \mathrm{L}$ for $\mathrm{Mn}$, 0.019 to $0.025 \mathrm{mg} / \mathrm{L}$ for $\mathrm{Zn}, 0.024$ to $0.033 \mathrm{mg} / \mathrm{L}$ for As) and $<0.001$ to $0.004 \mathrm{mg} / \mathrm{L}$ forHg, all of which were less than the FAO recommended maximum concentrations of elements in water ${ }^{1}$ for irrigation. $\mathrm{Cu}$, $\mathrm{Pd}, \mathrm{Cd}, \mathrm{Co}$ and $\mathrm{Cr}$ were below detection limits. Generally, water from the Marina-Park Lake was suitable, in respect of heavy metal concentrations, for the irrigation of vegetable farms, and specifically Site 2 was the most suitable site to draw water for this purpose.
Keywords: Toxic metals, essential elements, irrigation, water quality

\section{Introduction}

More than $70 \%$ of freshwater bodies in urban areas are irreplaceably used for vegetable growing [1], an activity that has served as a means of livelihood among small scale farmers in most developing countries[2].Urban vegetable cultivation has been fuelled by the increased awareness, positive perception and consumption of "organic vegetables"[3], and the increasing demand of the export markets for vegetables, particularly among West African countries [4, 5]. However, there are concerns in respect of the potential health risk of vegetables from these urban farms, principally those that use water from streams and lakes associated with human activity. Our earlier study (at the same location) had reported data in respect of the microbial safety (bacterial quality) of these vegetables and the water from a lake used for their irrigation[6]. In following with a preventative approach $[7,8]$,which is supported by the FAO [9], particularly to avert the 
rejection of the vegetables of these small holder low income farmers on the export markets, we extended our study by evaluating water from this lake, as to whether its toxic metal as well as the essential element contents were less than the FAO maximum recommended concentration for irrigation water; Noting that concentrations of toxic metals such as Pd, $\mathrm{Cd}$ and $\mathrm{Cr}$ in foods, beyond certain limits, have proven detrimental to human health [1,10-12].

The findings thereof formed the basis for advising farmers as to which location along the bank of the lake, was best to draw water for irrigation, and the call for regular monitoring of water bodies in urban areas used for agricultural purposes. This is in order to minimize the potential of the risk of heavy metal contamination through food crops.

\section{Methodology}

\section{Study Location}

The water samples for this study were obtained from the "Marina Park Lake", which is located at $5^{\circ} 41^{\prime} 46.5^{\circ} \mathrm{N}$ and $0^{\circ} 08^{\prime} 08.7^{\circ} \mathrm{W}$ and beside the Lakeside Marina Park, in the Greater Accra Region of Ghana. It covers an area of approximately $61,000 \mathrm{~m}^{2}$. The lake serves as a source of water for a number of human and animal related activities.

\section{Sample Collection and Analysis}

Duplicate water samples were collected at five different sites along the banks of the lake(fig.1), with sterile screw-capped plastic bottles (as per standard methods described in the guidelines of the American Public Health Association (APHA) and American Water Works Association (AWWA) [13, 14]. The kind and intensity of consistent (for a few months) human activity were also noted. The water samples collected were labelled and transported to the laboratory for analysis.

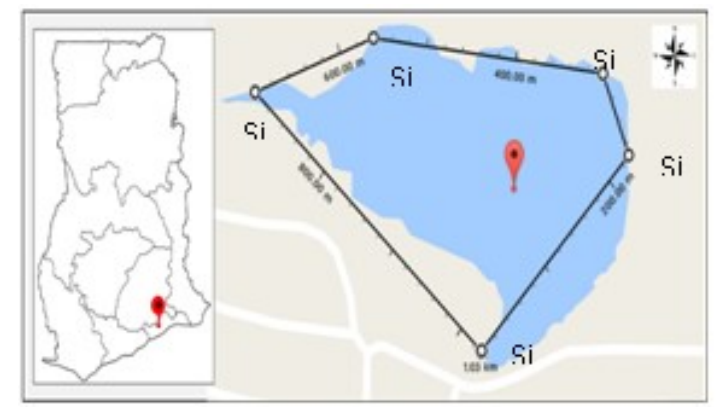

Figure 1: A google map of the "Marina Park Lake" showing the sites of collection of water samples
Sites were chosen based on access and insert is a map of Ghana indicating the location of the lake in the Greater Accra Region.

\section{Digestion Protocol}

The milestone Acid Digestion procedure was used, where $5 \mathrm{~mL}$ of the each water sample was measured into Teflon beakers, to this, $6 \mathrm{~mL}$ of concentrated $\mathrm{HNO}_{3}(65 \%)$ and $1 \mathrm{ml} \mathrm{H}_{2} \mathrm{O}_{2}(30 \%)$ were added. The Teflon beakers were covered with Teflon cups and loaded onto rotor and tightly secured using a rench or torque. The rotor was then placed in ETHOS 900 microwave oven and digested using a digestion programme [15].

\section{Atomic Absorption \\ Determination \\ Spectrophotometer}

Analysis of metals of interest was performed using a Varian model AA 240 FS Atomic Absorption Spectrophotometer with the recommended instrument parameters and detection limits for each metal determined [15].The physicochemical parameters investigated were $\mathrm{pH}$, Electrical Conductivity, hardness $\left(\mathrm{CaCO}_{3}\right)$ and Alkalinity, The analysis was carried out using the standard methods described by $[13,16]$.

\section{Results}

\section{Study Location}

The five sites from where the water samples were collected, were observed to have been associated with the human activities listed in Table 1 . The extent of these activates were scored on a scale of 1 to 5 , with 5 as the most active. 
International Journal of Trend in Scientific Research and Development (IJTSRD) ISSN: 2456-6470

Table 1: Human interactions and concentration of some chemical indicators of water quality at each sample collection sites.

\begin{tabular}{|c|c|c|c|c|c|c|c|c|c|c|}
\hline & & \multicolumn{7}{|c|}{ Concentration (mg/L) } & \multirow[b]{2}{*}{$\mathbf{p H}^{*}$} & \multirow[b]{2}{*}{$\begin{array}{c}\text { Conductivit } \\
\mathrm{y}(\mu \mathrm{S} / \mathrm{cm})\end{array}$} \\
\hline Source & $\begin{array}{l}\text { Human Activity } \\
\text { (Relative Score }^{*} \text { ) }\end{array}$ & $\mathbf{F}$ & Cl & $\mathrm{CaCO}_{3}$ & $\begin{array}{l}\text { Nitrat } \\
\text { e }\end{array}$ & $\mathrm{PO}_{4}^{-3}$ & $\mathrm{SO}_{4}^{-2}$ & Alkalinity & & \\
\hline Site 1 & $\begin{array}{l}\text { Regular washing of } \\
\text { cars and disposal of } \\
\text { solid waste. (4) }\end{array}$ & 0.230 & 84.0 & 212.0 & 1.511 & 0.072 & 21.9 & 140 & 7.0 & 1134 \\
\hline Site 2 & Washing of cloths. (2) & 0.210 & 211.9 & 228.0 & 1.520 & 0.077 & 23.1 & 108 & 7.0 & 1122 \\
\hline Site 3 & $\begin{array}{l}\text { Pumping of water for } \\
\text { irrigation, washing of } \\
\text { cloth, swimming. (3) }\end{array}$ & 0.220 & 197.9 & 212.0 & 1.486 & 0.069 & 23.0 & 110 & 7.0 & 1148 \\
\hline rSite 4 & $\begin{array}{l}\text { Fetching of water by } \\
\text { truck with pumps, } \\
\text { washing of cloths, } \\
\text { washing of cars, cattle } \\
\text { drinking sources and } \\
\text { main access to the } \\
\text { lake. (5) }\end{array}$ & 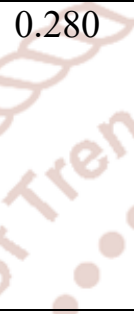 & $0^{\circ}$ & 268.0 & 1.531 & 0.081 & 24.2 & 134 & 7.0 & 1146 \\
\hline Site 5 & $\begin{array}{l}\text { Almost no direct } \\
\text { activity (1) }\end{array}$ & 0.210 & $\begin{array}{l}193.9 \\
\text { cerln }\end{array}$ & $\begin{array}{l}232.0 \\
2110\end{array}$ & 1.508 & $\begin{array}{l}0.078 \\
\text { nal }\end{array}$ & 23.4 & 116 & 7.0 & 1146 \\
\hline FAO & $\begin{array}{l}\text { Minimal human } \\
\text { activity }\end{array}$ & 1.0000 & & rol In & $<5.0 \mathrm{el}$ & $2.0 \mathrm{C}$ & 250.0 & - & $6-9$ & 2250 \\
\hline
\end{tabular}

${ }^{*}$ Relative score of intensity of human activity on a scale of 1 to 5 , where 5 is the most intense; ${ }^{*}$ The $\mathrm{pH}$ was semi-quantitatively determined with a $\mathrm{pH}$ paper

\section{Indicators of Water Quality}

Table 1 also presents the levels of the most indicators of the chemical quality of water for each of the study sites. Specifically, the concentration of Fluoride (F) ranged between $0.210 \mathrm{mg} / \mathrm{L}$ for sites 2 and 5 and $0.280 \mathrm{mg} / \mathrm{L}$ for site 4. Furthermore, while the concentration of $\mathrm{Cl}$ was lowest at site $1(84.0 \mathrm{mg} / \mathrm{L})$ and highest at site $2(211.9 \mathrm{mg} / \mathrm{L})$, the concentration of $\mathrm{CaCO}_{3}$ was lowest at sites 1 and $3(212.0 \mathrm{mg} / \mathrm{L})$ but highest at site $4(268 \mathrm{mg} / \mathrm{L})$. The concentration of Nitrate, Phosphate and Sulphate varied within ranges of $1.486 \mathrm{mg} / \mathrm{L}$ (site 3 ) to $1.531 \mathrm{mg} / \mathrm{L}$ (site 4 ); 0.069 $\mathrm{mg} / \mathrm{L}$ (site 3) to $0.081 \mathrm{mg} / \mathrm{L}$ (site 4) and $21.9 \mathrm{mg} / \mathrm{L}$ (site 1) to $24.2 \mathrm{mg} / \mathrm{L}$ (site 4) respectively. The physicochemical indicators ( $\mathrm{pH}$ and conductivity) of the water obtained from each of the five sites also varied within a narrow range.

\section{Metal Content}

The concentration of Mnin the water ranged between a relatively higher concentrations for three sites; $0.0514 \pm 0.001 \mathrm{mg} / \mathrm{L}$ for site $1 ; 0.0450 \pm 0.0008 \mathrm{mg} / \mathrm{L}$ for site 2 and $0.0491 \pm 0.0034 \mathrm{mg} / \mathrm{L}$ for site 4 to a relatively moderate concentration of $0.0240 \pm 0.008$ $\mathrm{mg} / \mathrm{L}$ for site 5 but was not detected in water from site 3 (Figure 2a). On the other hand, the concentrations of $\mathrm{Zn}$ were relatively moderate and within a narrower range; varying from $0.0191 \pm 0.0004 \mathrm{mg} / \mathrm{L}$ for site 2 , through $0.0203 \pm 0.0008 \mathrm{mg} / \mathrm{L}$ for site $5 ; 0.0229 \pm$ $0.0004 \mathrm{mg} / \mathrm{L}$ for sites 1 and 4 , to $0.0248 \pm 0.0008$ $\mathrm{mg} / \mathrm{L}$ for site 3.Similarly, the concentrations of Aswere also relatively moderate and varied within a narrow range. Mercury was only detected from sites 4 and 5 and its concentrations were relatively very low, compared to the concentrations of the other heavy metals (Fig.2a). The concentration of the following toxic metals $\mathrm{Pb}, \mathrm{Cd}, \mathrm{Cu}, \mathrm{Co}$ and $\mathrm{Cr}$ in the water from the five sites were below the detection limits of the 
assays used (data not shown). The concentration of Fe in the water varied from one site to the other within a wider range (Figure $2 b$ ); these were $0.4815 \pm 0.0128$ $\mathrm{mg} / \mathrm{L}$ and $0.4845 \pm 0.0008$ for sites 2 and 5 respectively, $0.7901 \pm 0.0026 \mathrm{mg} / \mathrm{L}$ and $0.7313 \pm$ $0.0045 \mathrm{mg} / \mathrm{L}$ for sites 3 and 1 respectively and 1.8161 $\pm 0.0041 \mathrm{mg} / \mathrm{L}$ for site 4 . The concentration of magnesium $(\mathrm{Mg})$ in the water from these five sites varied within a very narrow range (Fig. 2b). Specifically, sites 5 and 4 recorded $0.2183 \pm 0.0060$ $\mathrm{mg} / \mathrm{L}$ and $0.2194 \pm 0.0019 \mathrm{mg} / \mathrm{L}$ of $\mathrm{Mg}$ respectively, while sites 3, 2 and 1 recorded $0.2348 \pm 0.0023 \mathrm{mg} / \mathrm{L}$, $0.2359 \pm 0.0026 \mathrm{mg} / \mathrm{L}$ and $0.2531 \pm 0.004 \mathrm{mg} / \mathrm{L}$ in water from respectively.
In respect of the concentration of calcium (Ca) (Fig. $2 \mathrm{c}$ ), it varied between $49.6 \mathrm{mg} / \mathrm{L}$ and $65.6 \mathrm{mg} / \mathrm{L}$. Similarly, the concentration of sodium $(\mathrm{Na})$ ranged from $47.1 \mathrm{mg} / \mathrm{L}$ to $56.1 \mathrm{mg} / \mathrm{L}$. On the other hand, the recorded concentrations of potassium $(\mathrm{K})$ were between $6.9 \mathrm{mg} / \mathrm{L}$ and $11.7 \mathrm{mg} / \mathrm{L}$. The FAO recommended Maximum Concentration, as reported by Ayers and Westcot, (1985) are presented in the legend to figure 2. A comparison of the concentrations of each heavy metal between the five sites was conducted and the sites were ranged on a scale of 1 to 5 , in increasing order.

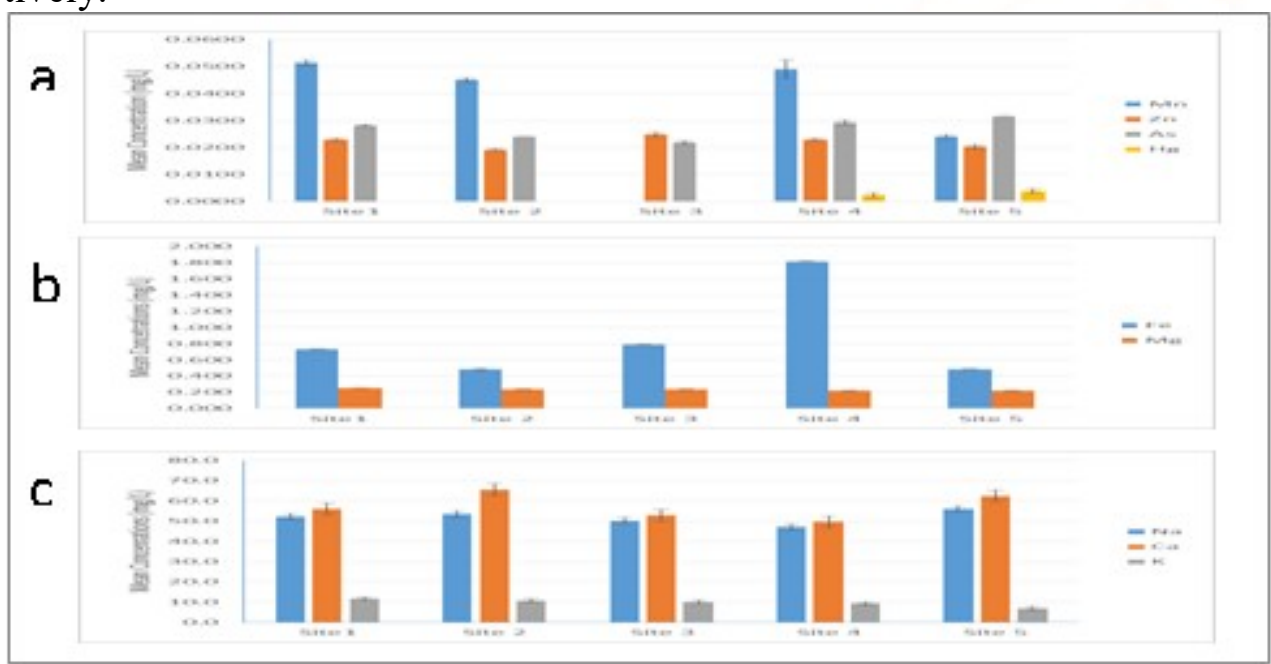

Figure 2: Toxic and essential metals concentrations in water from a Lake in use for irrigations of vegetables. FAO Recommended Maximum Concentration of these elements, in units of $\mathrm{mg} / \mathrm{L}$, are as follows;

Fe (5.00), Zn (2.00), Mn (0.20), As (0.10), Hg (0.00), Mg (0.20), K (300 ppm*), $\mathrm{Na}$ (69.00), Ca (80.00). Adapted from Ayers and Westcot, (1985) and *[17]

\section{DISCUSSION}

In pursuit of providing guidance to vegetable farmers regarding the location, along the bank of the Marina Park Lake, from which to draw water for irrigation, we determined whether the concentration of trace and other elements were above the FAO guideline or maximum limits for water used for irrigation (Figure 2). Our findings(Figures 2), indicated that five of the ten major heavy metals of significant health concern $(\mathrm{Pb}, \mathrm{Cd}, \mathrm{Cu}, \mathrm{Co}$ and $\mathrm{Cr}$ )were below detection limits (data not shown),implies a good indication of a water body potentially uncontaminated with toxic metals and therefore usable for irrigation. Further indications of this potential were that $\mathrm{Hg}$ was detected to be present at very low concentration and at only two of the five sites. Furthermore, the favourable usability of water from this lake for irrigation was indicated by the facts that the highest recorded concentrations of $\mathrm{Fe}, \mathrm{Zn}, \mathrm{Mn}$, and As were extremely lower than the
FAO recommended maximum concentrations in water for irrigation [9]. Additionally, the concentration of $\mathrm{Na}, \mathrm{K}$ and $\mathrm{Ca}$ (Figure 2c)were also below their FAO and the USA recommended maximum concentration in water for irrigation[17, 9]. Additionally, the levels of the other indicators of the chemical quality of water, which include $\mathrm{F}, \mathrm{CaCO}_{3}$, nitrate, phosphate, sulphate, $\mathrm{pH}$, conductivity and alkalinity were below the FAO recommended maximum levels[9], further indicating a low level of chemical pollution and a high potential usability of water from the Marina Park Lake for irrigation of urban vegetable farms.

These overall or generally very low concentrations of the metals may be due to the facts that the catchment area of this lake have not had, and continues not to have heavy and/or light industrial activity, as well as landfill sites, which are known to contribute significantly to highheavy/toxic metal pollution of water bodies[17-20]. 
However, in order to identify the most appropriate among these sites, to recommend to the farmers, comparing these findings and how they compare with the FAO recommendations imply that generally, water from the Eastern side of the Marina Park Lake (sites 2 and 3 ) is most suitable for irrigating vegetable farms. Among these sites, site 2 seems the most preferable location to draw water for irrigating the vegetable farms because it is the only site that did not record the highest relative concentration of any of the heavy metals but only a single second highest for $\mathrm{Mg}$. In addition, $\mathrm{Hg}$ was not detected in water from this site and it recorded the lowest relative concentration for $\mathrm{Fe}$ and the second lowest relative concentration of As. On the other hand, sites 1 and 3, although less preferable to site 2 are more preferable to site 4 and 5.The variation in the concentrations of the each heavy metal between the sites may have been influenced by the nature and extent of human activity at each site. Therefore, for site 4, which experienced the highest intensity of the human activities, which included automobiles related activity, it is intuitive to expect, as has been observed, that site 4 will record the highest concentrations of the heavy metals. However, the very low extent of human activity at site 5 does not explain the detection of $\mathrm{Hg}$ and relative higher concentrations of as at this site, but may partly explain the lower concentration of the other heavy metals. Furthermore, the relative low concentrations of the heavy metals for site 2 intuitively correlate with the low relative intensity and the low number of human activity at that location. Based on the findings, water from the Marina Park Lake generally was usable for the irrigations and drawing water from site 2 will results in the most reduced potential of toxic metal contamination of the vegetables.

\section{Limitations}

This study is limited by the lack of a study of data on the geology of the lake and it surrounding land area, which may have contributed to its elemental content [21, 22, 19].Other human activities, which may not have been noted by this study (those that occur at night) and the contribution of vegetation associated with the lake, may have influenced the findings[22, 23]. A furthering of this study analysing oil and vegetables from the farm lands will aid the appropriate identification of the major source contributing to the toxic and/or essential element in such vegetables, and the assessment of the potentially exposure to humans through the consumption of such vegetables, respectively.

\section{REFERENCES}

1. Shrivastava KBL, Mishra SP. Studies of Various Heavy Metal in Surface and Ground Water of Birsinghpur Town and its Surrounding Rural Area District Satna (M.P.). Curr World Environ. 2011;6:271-4.

2. Baroni L, Cenci L, Tettamanti M, Berati M. Evaluating the environmental impact of various dietary patterns combined with different food production systems. Eur J ClinNutr. 2007;61:279-86.

3. Gupta S, Jena V, Jena S, Davić N, Matić N, Radojević D, et al. Assessment of heavy metal contents of green leafy vegetables. Croat J Food Sci Technol. 2013;5:53-60.

4. Njume, C, Goduka, NI, George, G. Indigenous leafy vegetables (imifino, morogo, muhuro) in South Africa: A rich and unexplored source of nutrients and antioxidants. Afr $\mathrm{J}$ Biotechnol. 2014; $13: 1933-42$.

5. Slavin JL, Lloyd B. Health Benefits of Fruits and Vegetables. AdvNutrInt Rev J. 2012;3:506-16.

6. Doe ED, Awua AK, Larbi DK. Microbiological Quality Monitoring of Water from a Lake Associated with Varying Human Activity. Int J Healthc Sci. 2016;4:160-165.

7. Shammi M, Kashem MA, Rahman MM, Hossain MD, Rahman R, Uddin MK. Health risk assessment of textile effluent reuses as irrigation water in leafy vegetable Basellaalba. Int J Recycl Org Waste Agric. 2016;5:113-23.

8. Aboyeji OS, Ogunkoya OO. Assessment of surface water quality of inland valleys for cropping in SW Nigeria. Appl Water Sci. 2015. doi:10.1007/s13201-015-0309-8.

9. Ayers RS, Westcot DW. Water quality for agriculture. Rome: Food and Agriculture Organization of the United Nations; 1985.

10. Nazif W, Perveen S, Shah SA. Evaluation of irrigation water for heavy metals of Akbarpura area. J AgricBiol Sci. 2006;1:51-4.

11. Jarup L. Hazards of heavy metal contamination. Br Med Bull. 2003;68:167-82. 
12. Bruins MR, Kapil S, Oehme FW. Microbial Resistance to Metals in the Environment. Ecotoxicol Environ Saf. 2000;45:198-207.

13. American Public Health Association. Standard methods: for the examination of water and wastewater. 20. ed. Washington: American Public Health Ass; 1998.

14. Greenberg AE, Clesceri LS, Eaton AD. Standard methods for the examination of water and waste water. 18th edition. Washington, DC: American Public Health Association; 1992.

15. Doe ED, Awua AK, Gyamfi OK, Bentil NO. Levels of Selected Heavy Metals in Wheat Flour on the Ghanaian Market: A Determination by Atomic Absorption Spectrometry. Am J Appl Chem. 2013;1:17.

16. Clesceri LS, Greenberg AE, editors. Standard methods: for the examination of water and wastewater. 20. ed. Washington: American Public Health Association; 1998.

17. Nagaraju A, Sunil Kumar K, Thejaswi A. Assessment of groundwater quality for irrigation: a case study from Bandalamottu lead mining area, Guntur District, Andhra Pradesh, South India. Appl Water Sci. 2014;4:385-96.

18. Bichi MH, Bello UF. Heavy Metal Pollution in Surface and Ground Waters Used for Irrigation along River Tatsawarki in the Kano, Nigeria. IOSR J Eng. 2013;3:01-9.

19. Kanmani S, Gandhimathi R. Investigation of physicochemical characteristics and heavy metal distribution profile in groundwater system around the open dump site. Appl Water Sci. 2013;3:387-99.

20. Bala M, Shehu RA, Lawal M. Determination of the level of some heavy metals in water collected from two pollution - prone irrigation areas around Kano Metropolis. Bayero J Pure Appl Sci. 2008;1:36-38.

21. Kumar VS, Amarender B, Dhakate R, Sankaran S, Kumar RK. Assessment of groundwater quality for drinking and irrigation use in shallow hard rock aquifer of Pudunagaram, Palakkad District Kerala. Appl Water Sci. 2016;6:149-67.

22. Asare-Donkor NK, Kwaansa-Ansah EE, Opoku F, Adimado AA. Concentrations, hydrochemistry and risk evaluation of selected heavy metals along the Jimi River and its tributaries at Obuasi a mining enclave in Ghana. Environ Syst Res. 2015;4. doi:10.1186/s40068015-0037-y.

23. Boateng TK, Opoku F, Acquaah SO, Akoto O. Pollution evaluation, sources and risk assessment of heavy metals in hand-dug wells from EjisuJuaben Municipality, Ghana. Environ Syst Res. 2015;4. doi:10.1186/s40068-015-0045-y. 